\title{
Mycobacterium abscessus Lung Infection: A Case Report
}

\author{
Pan Pan Wang, Charles-André Bray, Simon Grandjean Lapierre, Hafid Soualhine, and Fanny Arbour
}

\section{INTRODUCTION}

$\mathrm{N}$ ontuberculous mycobacteria (NTM) are ubiquitous, and more than 150 species have been identified. ${ }^{1,2}$ These low-virulence mycobacteria are known to cause mostly opportunistic infections in immunocompromised patients, although they are increasingly seen in normal hosts. ${ }^{1,2}$ Mycobacterium abscessus complex is a rapidly growing NTM, which was the second most commonly isolated NTM pulmonary pathogen in British Columbia and Alberta in 2013. ${ }^{2}$ In Quebec, M. abscessus complex represented $11.4 \%$ of the 474 mycobacteria samples received for susceptibility testing by the Laboratoire de santé publique du Québec in the period April 2012 to March 2013. ${ }^{3}$ Multiple-drug resistance and frequent relapses make the treatment of $M$. abscessus lung infections clinically challenging. ${ }^{1}$ This case report discusses the management of pulmonary $M$. abscessus infection in a patient who underwent prolonged antimicrobial treatment and surgery and in whom several antimicrobial adverse effects were suspected.

\section{CASE REPORT}

In April 2014, a 36-year-old man presented with a 1-year history of fever, dyspnea, pleuritic pain, chronic productive cough, and 15-kg weight loss (body weight at time of presentation $55 \mathrm{~kg}$ ). ${ }^{*}$ He had immigrated 6 months earlier from West Africa and had received medical coverage 2 days before the initial consultation. His medical history included treated pulmonary tuberculosis in 2002 and pulmonary aspergilloma leading to right superior lobectomy in March 2013. He had no history of HIV infection or other forms of immunosuppression. He was not taking any medication and had no known allergies.

\footnotetext{
*The patient gave written informed consent for publication of this case report.
}

Initial examination showed fever $\left(38.4^{\circ} \mathrm{C}\right)$, tachycardia $(135$ beats/min) without hemodynamic instability, a normal respiratory rate, and the presence of multiple cutaneous fistulas with mucopurulent discharge at the site of the prior lobectomy incision.

Initial chest computed tomography (CT) showed the following features: multiple cavities and nodules in the right inferior and middle lobes; several fistulas between the skin, the pleural space, and the lung parenchyma; and lytic lesions of the right sixth rib. Both lungs showed important atelectasis and cylindrical bronchiectasis, especially on the right side. The left lung also contained multiple small nodules and a $20-\mathrm{mm}$ air cavity. Bone scintigraphy later corroborated the bone infection.

Bronchoscopy showed no sign of hemoptysis. Spirometry showed a decreased forced expiratory volume in $1 \mathrm{~s}$ of $1.88 \mathrm{~L}$ ( $44 \%$ of the predicted value), with total pulmonary capacity of $3.11 \mathrm{~L}$ ( $56 \%$ of the predicted value). The initial leukocyte count was $11.3 \times 10^{9} / \mathrm{L}$ (normal range 4.0-11.0 $\times 10^{9} / \mathrm{L}$ ), hemoglobin was $75 \mathrm{~g} / \mathrm{L}$ (normal range 140-175 g/L), and platelet count was $768 \times 10^{9} / \mathrm{L}$ (normal range $150-400 \times 10^{9} / \mathrm{L}$ ). C-reactive protein was elevated, at $85.8 \mathrm{mg} / \mathrm{L}$. Repeat culture of blood, induced sputum, fistula discharge, and bronchoalveolar lavage (BAL) fluid yielded negative results for aerobic, anaerobic, and fungal organisms. Acid-fast colouration, Mycobacterium tuberculosis polymerase chain reaction assay, and HIV serology testing all gave negative results.

The patient was admitted to the pneumology unit. On day 9 of the hospital stay, after blood transfusions and supportive care, mycobacterial culture of the BAL fluid confirmed the presence of a rapidly growing mycobacterium. On day 14, the Laboratoire de santé publique du Québec identified the pathogen as $M$. abscessus complex. Empiric treatment with amikacin, imipenem, azithromycin, and moxifloxacin was started immediately (Figure 1), following the guidelines of the American Thoracic Society/Infectious Diseases Society of 


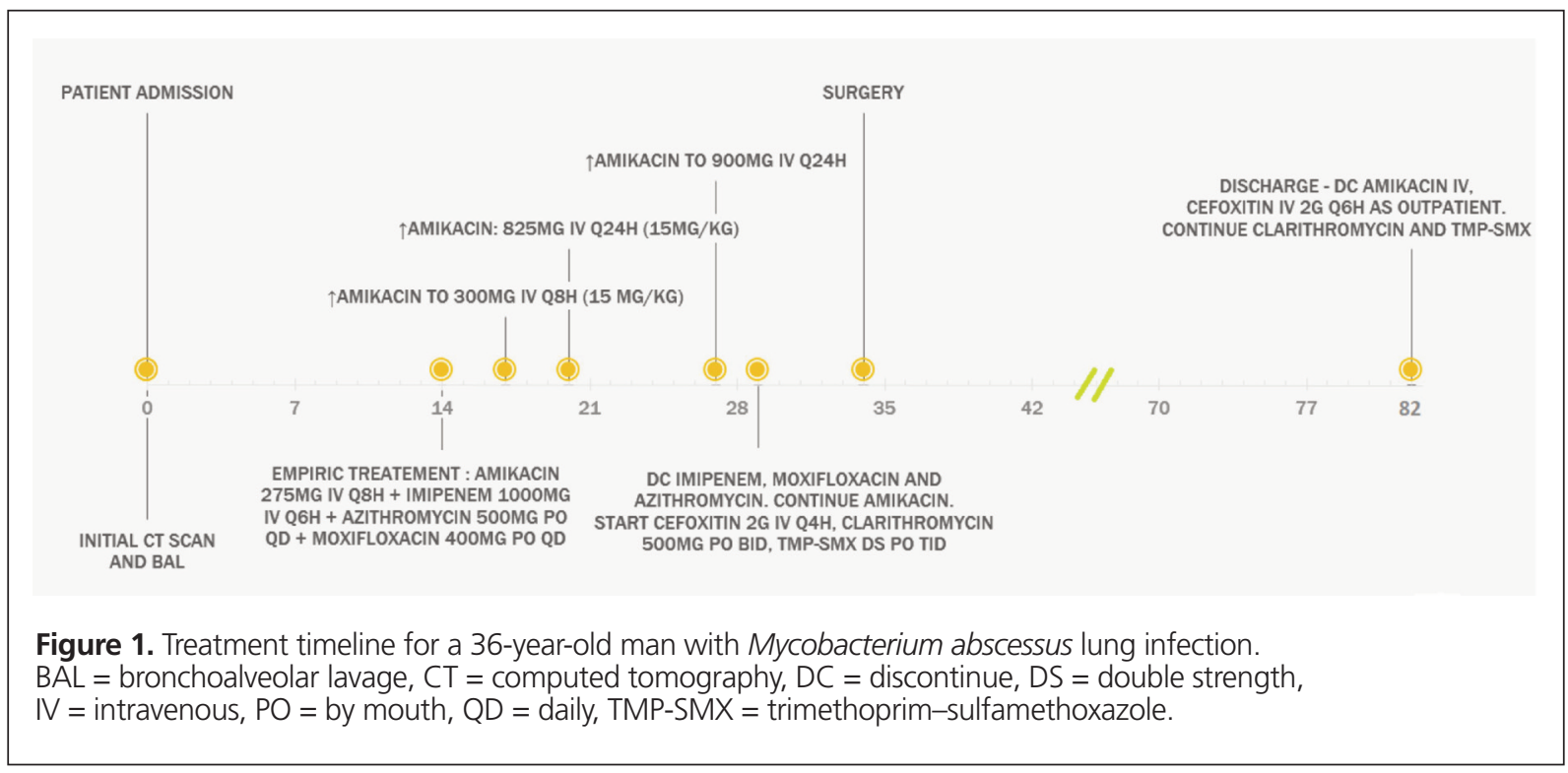

America (ATS/IDSA) and according to the clinical expertise of the medical microbiologist and infectious disease clinician. On day 20, the National Microbiology Laboratory (Public Health Agency of Canada) identified the subspecies as M. abscessus ssp. abscessus. On day 28, treatment was adjusted, according to the susceptibility profile (Table 1), to amikacin, cefoxitin, clarithromycin, and trimethoprim-sulfamethoxazole (TMP-SMX). At that time, the patient still had fever, right pleuritic pain, and mild dyspnea, although the fistula discharge had decreased, and he had gained $5 \mathrm{~kg}$ body weight.

On day 34, the patient underwent right pneumonectomy and partial removal of the right third, fifth, and sixth ribs, the latissimus dorsi muscle, and the right scapula. An open thoracic window was left in place, in case further intervention was needed. Specific polymerase chain reaction and gene sequencing assays (for $r r s$ and $h s p 65$ genes) on pathology specimens later confirmed the diagnosis of pulmonary $M$. abscessus.

One month after the surgery, repeat chest CT showed decreased infiltrates and shrinkage of the nodules in the left lung. Culture results for control BAL fluid and induced sputum were still negative at 7 and 10 months, respectively, after the surgery. At about day 70, the patient had mild neutropenia (nadir of $1.1 \times 10^{9} / \mathrm{L}$ [normal range $\left.\left.1.8-8.2 \times 10^{9} / \mathrm{L}\right]\right)$. However, he remained clinically stable, and the treatment was continued.

The patient was discharged on day 82 , and the open thoracic window was closed surgically with a muscle flap on day 95. There was close postdischarge follow-up by the medical microbiologists and infectious disease team. Because of elevation of serum creatinine (from baseline of $65 \mu \mathrm{mol} / \mathrm{L}$ to $117 \mu \mathrm{mol} / \mathrm{L}$ at discharge), the amikacin was stopped at discharge, without rechallenge. Soon after discharge, the patient reported peripheral neuropathy, with a painful burning sensation in the limbs. The condition was relieved by low-dose

\section{Table 1. Antibiotic Susceptibility of Identified Mycobacterium abscessus ssp. abscessus}

\begin{tabular}{lc} 
Antibiotic & $\begin{array}{c}\text { Minimum Inhibitory } \\
\text { Concentration (mg/L) }\end{array}$ \\
\hline Resistant & 4 \\
Ciprofloxacin & 4 \\
Moxifloxacin & \\
Susceptible & 16 \\
Cefoxitin & 4 \\
Imipenem & 4 \\
Amikacin & 0.25 \\
Clarithromycin & $2-38$ \\
TMP-SMX & $\leq 1$ \\
Linezolid &
\end{tabular}

TMP-SMX = trimethoprim-sulfamethoxazole.

pregabalin. The patient completed 6 months of outpatient treatment with parenteral cefoxitin. Oral clarithromycin and TMP-SMX were stopped after 18 months of treatment. He was followed monthly for the first 4 months and then every 2 months until recently (for a total of 16 months of outpatient follow-up). At the most recent appointment, the patient had resumed normal activity and was looking for a job. He weighed $70 \mathrm{~kg}$, and his inflammatory parameters had normalized.

\section{DISCUSSION}

Mycobacterium abscessus complex is an ubiquitous, rapidly growing mycobacterium. ${ }^{1,2}$ The lungs are the most frequent site of infection, and $M$. abscessus infections progress slowly if left untreated. ${ }^{1,4} \mathrm{~A}$ history of chronic cough is often present initially, whereas fever and constitutional symptoms are seen with disease progression. ${ }^{1}$ Typical radiologic findings include nodular opacities and multifocal bronchiectasis. ${ }^{1,4}$ Previous pulmonary tuberculosis and bronchiectasis are predisposing conditions for M. abscessus pulmonary infection. ${ }^{1}$ Table 2 summarizes the 
This single copy is for your personal, non-commercial use only.

For permission to reprint multiple copies or to order presentation-ready copies for distribution, contact CJHP at cjhpedit@cshp.ca

Table 2. Published Case Reports of Mycobacterium abscessus Lung Infection in Immunocompetent Hosts without Cystic Fibrosis

\begin{tabular}{|c|c|c|c|c|}
\hline Study & Patients & History & Treatment & Outcome \\
\hline $\begin{array}{l}\text { Tanaka et al. } \\
(2002)^{5}\end{array}$ & 63-year-old man & $\begin{array}{l}\text { 3-year history of } \\
\text { M. abscessus infection; } \\
\text { previous lobectomy for } \\
\text { pulmonary tuberculosis }\end{array}$ & $\begin{array}{l}\text { For } 8 \text { weeks: } \\
\text { Clarithromycin } 10 \mathrm{mg} / \mathrm{kg} \text { PO daily } \\
\text { Levofloxacin } 5 \mathrm{mg} / \mathrm{kg} \text { PO daily } \\
\text { Imipenem } 25 \mathrm{mg} / \mathrm{kg} \text { IV daily } \\
\text { Amikacin } 5 \mathrm{mg} / \mathrm{kg} \text { IV daily } \\
\text { Relapse } 4 \text { months later: } \\
\text { Add ethambutol and TMP-SMX, but } \\
\text { discontinued because of skin rash } \\
\text { Relapse: } \\
\text { Add faropenem } 10 \mathrm{mg} / \mathrm{kg} \text { PO }\end{array}$ & $\begin{array}{l}\text { Survival, with } \\
\text { intermittent excretion } \\
\text { of } M . \text { abscessus in } \\
\text { sputum }\end{array}$ \\
\hline $\begin{array}{l}\text { Yano et al. } \\
(2007)^{6}\end{array}$ & $\begin{array}{l}\text { 73-year-old } \\
\text { woman }\end{array}$ & $\begin{array}{l}\text { No previous major illness, } \\
\text { HIV-negative }\end{array}$ & $\begin{array}{l}\text { Meropenem } 1000 \text { mg/day IV } \\
\text { Amikacin } 200 \text { mg/day IV } \\
\text { Clarithromycin } 400 \text { mg/day PO } \\
\text { Minomycin PO, dose not specified }\end{array}$ & $\begin{array}{l}\text { Survival, with complete } \\
\text { resolution of lung } \\
\text { opacity (initial } \\
\text { paradoxical worsening } \\
\text { on CT, but clinically } \\
\text { asymptomatic) }\end{array}$ \\
\hline $\begin{array}{l}\text { Sugino et al. } \\
(2009)^{7}\end{array}$ & $\begin{array}{l}\text { 56-year-old } \\
\text { woman }\end{array}$ & $\begin{array}{l}\text { Pulmonary tuberculosis; } \\
\text { 4-year history of } \\
\text { M. abscessus lung } \\
\text { infection }\end{array}$ & $\begin{array}{l}\text { For } 4 \text { weeks: } \\
\text { Imipenem/cilastatin } 1000 \mathrm{mg} / \text { day IV } \\
\text { Amikacin } 300 \mathrm{mg} / \text { day IV } \\
\text { Subsequent treatment: } \\
\text { Clarithromycin } 400 \mathrm{mg} / \text { day PO } \\
\text { Faropenem } 400 \mathrm{mg} / \text { day PO } \\
\text { Pneumonectomy }\end{array}$ & $\begin{array}{l}\text { Survival; radiographic } \\
\text { improvement of small } \\
\text { lung nodules; no } \\
\text { relapse for } 2 \text { years }\end{array}$ \\
\hline \multirow[t]{2}{*}{$\begin{array}{l}\text { Varghese et al. } \\
(2012)^{8}\end{array}$} & 30-year-old man & $\begin{array}{l}\text { HIV-negative, no history } \\
\text { of previous TB or chronic } \\
\text { pulmonary disorders }\end{array}$ & Clarithromycin 500 mg PO bid × 8 weeks & $\begin{array}{l}\text { Survival; result of } \\
\text { sputum culture negative } \\
1 \text { month after start of } \\
\text { the treatment }\end{array}$ \\
\hline & 40-year-old man & Not reported & Clarithromycin 500 mg PO bid × 8 weeks & $\begin{array}{l}\text { Survival; result of } \\
\text { sputum culture negative } \\
\text { for } M \text {. abscessus after } \\
42 \text { days of treatment }\end{array}$ \\
\hline $\begin{array}{l}\text { Haverkamp et al. } \\
(2012)^{9}\end{array}$ & $\begin{array}{l}\text { 42-year-old } \\
\text { woman }\end{array}$ & $\begin{array}{l}\text { Mild cystic fibrosis } \\
\text { phenotype; treated for } \\
\text { pulmonary Mycobacterium } \\
\text { avium complex infection } \\
\text { for } 14 \text { years and for } \\
\text { M. abscessus infection } \\
\text { for } 10 \text { years }\end{array}$ & $\begin{array}{l}\text { Clarithromycin, rifampicin, ethambutol } \\
\text { After disease progression: } \\
\text { Meropenem IV } \\
\text { Tobramycin IV }\end{array}$ & Death \\
\hline Koh et al. $(2012)^{10}$ & $\begin{array}{l}\text { 26-year-old } \\
\text { woman }\end{array}$ & Pulmonary sequestration & $\begin{array}{l}\text { Ceftriaxone and azithromycin } \times 1 \text { week } \\
\text { Surgical resection of sequestration } \\
\text { Amikacin and cefoxitin IV } \times 1 \text { week } \\
\text { Clarithromycin PO } \times 12 \text { weeks }\end{array}$ & $\begin{array}{l}\text { Survival, with no relapse } \\
\text { by } 36 \text { months after } \\
\text { surgery }\end{array}$ \\
\hline $\begin{array}{l}\text { Duan et al. } \\
(2012)^{11}\end{array}$ & $\begin{array}{l}\text { 61-year-old } \\
\text { woman }\end{array}$ & Recurrent pulmonary TB & $\begin{array}{l}\text { Clarithromycin, imipenem } \times 2 \text { weeks } \\
\text { Cefoxitin } \times 2 \text { weeks } \\
\text { Doxycycline and levofloxacin } \times 19 \text { months }\end{array}$ & $\begin{array}{l}\text { Survival; result of } \\
\text { sputum culture negative } \\
\text { at } 3 \text { months and at } \\
\text { end of treatment }\end{array}$ \\
\hline $\begin{array}{l}\text { Kurahara et al. } \\
(2013)^{12}\end{array}$ & 71-year-old man & $\begin{array}{l}\text { Silicosis and COPD; } \\
\text { HIV-negative; co-infection } \\
\text { with Mycobacterium } \\
\text { kansasii and } \\
\text { Mycobacterium avium } \\
\text { complex }\end{array}$ & $\begin{array}{l}\text { Imipenem/cilastatin } 1500 \text { mg/day } \\
\text { Amikacin } 300 \text { mg/day IV }\end{array}$ & $\begin{array}{l}\text { Death } 15 \text { months after } \\
\text { first identification of } \\
\text { M. abscessus }\end{array}$ \\
\hline $\begin{array}{l}\text { Duan et al. } \\
(2013)^{13}\end{array}$ & $\begin{array}{l}16 \text { patients, } \\
29-76 \text { years of age, } \\
\text { with new } \\
\text { M. abscessus } \\
\text { pulmonary infection }\end{array}$ & $\begin{array}{l}\text { Only } 5 \text { patients } \\
\text { underwent medical } \\
\text { therapy }\end{array}$ & $\begin{array}{l}\text { Cefoxitin } 2000 \text { mg IV q12 } \mathrm{h} \times \text { first } \\
12 \text { weeks } \\
\text { Amikacin } 400 \text { mg IV qday } \times \text { first } 12 \text { weeks } \\
\text { Clarithromycin } \\
\text { Moxifloxacin }\end{array}$ & $\begin{array}{l}\text { Of the } 5 \text { patients who } \\
\text { underwent medical } \\
\text { therapy, } 2 \text { patients had } \\
\text { clinical and radiologic } \\
\text { improvement, and } \\
1 \text { patient had no } \\
\text { improvement } \\
\text { Of the } 11 \text { patients who } \\
\text { did not receive antimicro- } \\
\text { bial therapy, } 1 \text { patient } \\
\text { died and } 5 \text { had new } \\
\text { pulmonary lesions }\end{array}$ \\
\hline
\end{tabular}

$\overline{C O P D}=$ chronic obstructive pulmonary disease, $\mathrm{CT}=$ computed tomography, IV = intravenous, $\mathrm{PO}=$ by mouth, $\mathrm{TB}=$ tuberculosis, TMP-SMX = trimethoprim-sulfamethoxazole. 
published case reports of $M$. abscessus pulmonary infections in immunocompetent patients. ${ }^{5-13}$ These cases were identified in PubMed with the keywords "Mycobacterium abscessus" and "pulmonary", and selection was limited to cases in immunocompetent hosts without cystic fibrosis. Two of the patients were treated with macrolide alone for 8 weeks $^{8}$; however, the efficacy of these regimens to prevent relapse cannot be determined because of the short duration of follow-up. In most of the published case reports at least 2 agents, often including a macrolide and an aminoglycoside, were combined for a variable duration of treatment..$^{5-7,9,11,13}$ However, the variations in follow-up duration and clinical outcome make it difficult to compare the efficacy of these regimens. Publication of additional case series is needed to document the optimal treatment of M. abscessus lung infections.

In 2007, ATS and IDSA published a joint guideline on the management of NTM diseases, including $M$. abscessus infections. ${ }^{1}$ Given the lack of clinical studies, treatment in the case presented here was based on these guidelines and expert opinion. Because $M$. abscessus is resistant to many drugs,

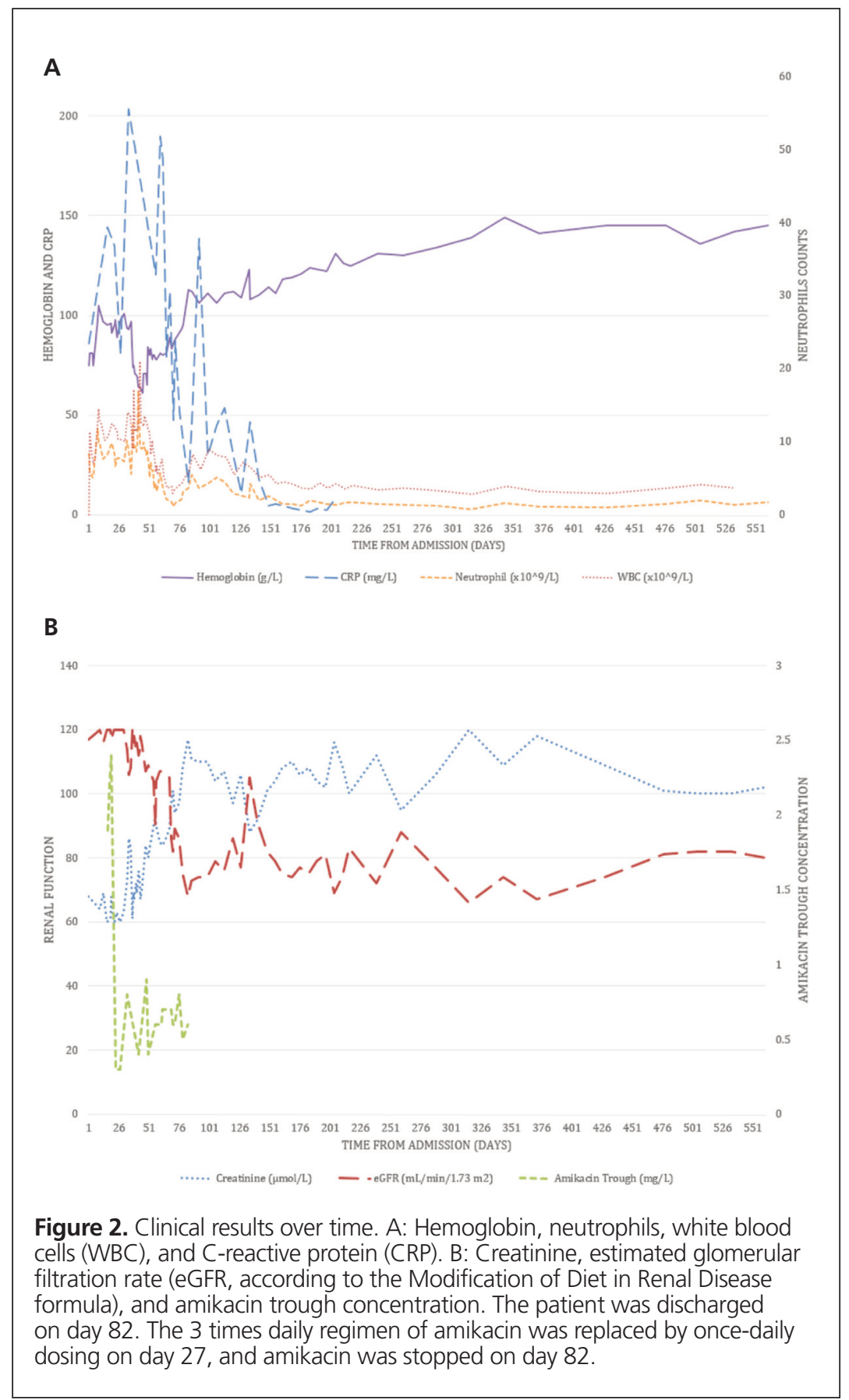


including antituberculous agents, ${ }^{1}$ identification of the subspecies and determination of drug susceptibility were crucial to choosing the appropriate treatment. Consistent with the guideline's recommendation and pathogen susceptibility, the patient received quadruple therapy with amikacin, cefoxitin, clarithromycin, and TMP-SMX. Surgery is essential in cases of extensive disease, focal abscess formation, and when drug therapy alone cannot control disease progression. ${ }^{1}$ The patient in this case was initially deemed too frail to undergo surgery. Therefore, this medical treatment was given for 34 days to lessen the microbial burden, and surgery was performed later.

Once surgery has been performed, further antibiotic treatment is necessary to maintain negative results on sputum culture for at least 12 months. However, there is currently no antibiotic regimen that has been shown to consistently achieve this goal. ${ }^{1}$ Amikacin (10-15 mg/kg per day) and high-dose cefoxitin $(12 \mathrm{~g} /$ day $)$ are the cornerstones of therapy for $M$. abscessus infections. ${ }^{1}$ Macrolides are the only oral agents demonstrating consistent in vitro activity against $M$. abscessus, although they are insufficient, on their own, to cure the disease. ${ }^{1}$ Mycobacterium abscessus ssp. abscessus carries an erm gene that provides in vivo inducible resistance to macrolides, but this may not be revealed by in vitro susceptibility tests. ${ }^{14}$ In contrast, $M$. abscessus ssp. massiliense is most often sensitive to macrolides. ${ }^{15}$ The TMP-SMX was added as a fourth agent, for extra coverage in case of resistance to any of the other medications.

Despite the occurrence of adverse drug reactions in this case, the antibiotic therapy was maintained because of the seriousness of the patient's condition and the lack of alternatives. His neutropenia might have been associated with the use of high-dose cefoxitin ${ }^{1,16}$ but might also have been attributable to the chronic infection. The patient remained mildly neutropenic (neutrophil count between $1 \times 10^{9} / \mathrm{L}$ and $1.5 \times 10^{9} / \mathrm{L}$ ), even after the cefoxitin was stopped on day 202 (see Figure 2A). However, no infection developed, nor did the patient require other specific treatment.

The patient's serum creatinine rose gradually, despite adequate fluid repletion and hemodynamic stability. Other than the antibiotics, the patient did not receive any nephrotoxic medication. The results of urinalysis and other laboratory tests were unremarkable. Possible causes of the renal injury were nephrotoxicity associated with amikacin, ${ }^{17}$ concomitant use of cephalosporin and aminoglycoside, ${ }^{17}$ and the competition of creatinine tubular secretion with TMP-SMX (Naranjo score 3 , indicating possible adverse reaction). ${ }^{18}$ The therapeutic concentration of amikacin (see Figure 2B) was monitored by a clinical pharmacist. Although without strong evidence, oncedaily dosing of amikacin was used as a reasonable alternative to 3 times daily dosing in the treatment of $M$. abscessus infection. ${ }^{1}$ A target trough concentration of $\leq 1 \mathrm{mg} / \mathrm{L}$ was used for once-daily dosing, which is a good predictor of drug clearance and avoidance of nephrotoxicity. ${ }^{19,20}$ At follow-up, the patient's serum creatinine remained stable $(\leq 120 \mu \mathrm{mol} / \mathrm{L}$ [normal range 53-120 $\mu \mathrm{mol} / \mathrm{L}$ ], with estimated glomerular filtration rate, according to the Modification of Diet in Renal Disease formula, of about $80 \mathrm{~mL} / \mathrm{min}$ per $1.73 \mathrm{~m}^{2}$ ), even though he had gained considerable muscle mass by the time amikacin was stopped.

The neurology service was consulted for the peripheral neuropathy, but the results of electromyography were inconclusive. Prolonged treatment with both TMP-SMX (Naranjo score 4) $)^{18,21}$ and cefoxitin (Naranjo score 4) ${ }^{16,21}$ indicated a possible adverse reaction. In addition, local inflammation and nutritional deficiencies could not be excluded as possible causes of the peripheral neuropathy.

\section{CONCLUSION}

Treatment of $M$. abscessus pulmonary infection is clinically challenging because of the organism's resistance to many antibiotics and the unfavourable adverse reaction profile of the currently recommended therapy. ${ }^{1}$ This article has discussed the management of severe $M$. abscessus lung infection in a 36-yearold man who received prolonged drug therapy and surgery and who had no clinical relapse after 18 months of follow-up.

\section{References}

1. Griffith DE, Aksamit T, Brown-Elliott BA, Catanzaro A, Daley C, Gordin F, et al.; ATS Mycobacterial Diseases Subcommittee; American Thoracic Society; Infectious Disease Society of America. An official ATS/IDSA statement: diagnosis, treatment, and prevention of nontuberculous mycobacterial diseases. Am J Respir Crit Care Med. 2007;175(4): 367-416. Erratum in: Am J Respir Crit Care Med. 2007;175(7):744-5 [dosage error].

2. Behr M, Jarand J, Marras TK. Nontuberculous mycobacteria. In: Menzies $\mathrm{D}$, editor. Canadian tuberculosis standards. 7 th ed. Ottawa (ON): Public Health Agency of Canada; 2013. p. 279.

3. Tremblay C, Fauvel M. Rapport d'activités 2012-2013 du Laboratoire de santé publique du Québec. Québec (QC): Institut national de santé publique du Québec; 2013.

4. Philley JV, Wallace RJ Jr. Chapter 132: Diseases due to nontuberculous mycobacteria. In: Grippi MA, Elias JA, Fishman JA, Kotloff RM, Pack AI, Senior RM, editors. Fishman's pulmonary diseases and disorders. New York (NY): McGraw-Hill Education; 2015 [cited 2016 May 27]. Available from: http://accessmedicine.mhmedical.com/content.aspx? bookid $=1344 \&$ Sectionid $=81199911$. Subscription required to access content.

5. Tanaka E, Kimoto T, Tsuyuguchi K, Suzuki K, Amitani R. Successful treatment with faropenem and clarithromycin of pulmonary Mycobacterium abscessus infection. I Infect Chemother. 2002;8(3):252-5.

6. Yano S, Kobayashi K, Kato K, Tokuda Y, Ikeda T, Takeyama H. Paradoxical worsening of pulmonary Mycobacterium abscessus. Respir Med. 2007; 101(4):868-70.

7. Sugino K, Kobayashi M, Iwata M, Gocho K, Kaburaki K, Muramatsu $\mathrm{Y}$, et al. Successful treatment with pneumonectomy for pulmonary Mycobacterium abscessus infection. Intern Med. 2009;48(6):459-63.

8. Varghese B, Shajan SE, Al MO, Al-Hajoj SA. First case report of chronic pulmonary lung disease caused by Mycobacterium abscessus in two immunocompetent patients in Saudi Arabia. Ann Saudi Med. 2012; 32(3):312-4.

9. Haverkamp MH, van Wengen A, de Visser AW, van Kralingen KW, van Dissel JT, van de Vosse E. Pulmonary Mycobacterium abscessus: a canary in the cystic fibrosis coalmine. J Infect. 2012;64(6):609-12. 
10. Koh WJ, Hong G, Kim K, Ahn S, Han J. Pulmonary sequestration infected with nontuberculous mycobacteria: a report of two cases and literature review. Asian Pac J Trop Med. 2012;5(11):917-9.

11. Duan HF, Huang XR, Wang J, Chu NH. Mycobacterium abscessus lung disease in a patient with previous pulmonary tuberculosis. Southeast Asian J Trop Med Public Health. 2012;43(4):959-63.

12. Kurahara Y, Tachibana K, Tsuyuguchi K, Suzuki K. Mixed pulmonary infection with three types of nontuberculous mycobacteria. Intern Med. 2013;52(4):507-10.

13. Duan HF, Chu NH, Wang QF, Wang J, Huang HR, Liang Q. [Mycobacterium abscessus group lung disease: case reports and review of the literature]. Zhonghua Jie He He Hu Xi Za Zhi. [Chinese J Tuberc Respir Dis.] 2013;36(9):671-4. In Chinese.

14. Choi GE, Shin SJ, Won CJ, Min KN, Oh T, Hahn MY, et al. Macrolide treatment for Mycobacterium abscessus and Mycobacterium massiliense infection and inducible resistance. Am J Respir Crit Care Med. 2012; 186(9):917-25.

15. Koh WJ, Jeon K, Lee NY, Kim BJ, Kook YH, Lee SH, et al. Clinical significance of differentiation of Mycobacterium massiliense from Mycobacterium abscessus. Am J Respir Crit Care Med. 2011;183(3):405-10.

16. Cephalosporins. In: Aronson JK, editor. Meyler's side effects of drugs: the international encyclopedia of adverse drug reactions and interactions. 15th ed. Amsterdam (Netherlands): Elsevier; 2006. pp. 688-701.

17. Aminoglycoside antibiotics. In: Aronson JK, editor. Meyler's side effects of drugs: the international encyclopedia of adverse drug reactions and interactions. 15th ed. Amsterdam (Netherlands): Elsevier; 2006. pp. 118-36.

18. Trimethoprim and co-trimoxazole. In: Aronson JK, editor. Meyler's side effects of drugs: the international encyclopedia of adverse drug reactions and interactions. 15th ed. Amsterdam (Netherlands): Elsevier; 2006. pp. 3510-24.

19. Hatala R, Dinh T, Cook DJ. Once-daily aminoglycoside dosing in immunocompetent adults: a meta-analysis. Ann Intern Med. 1996; 124(8):717-25.

20. Murphy J, Matthias K. Aminoglycosides. In: Murphy JE, editor. Clinical pharmacokinetics. Bethesda (MD): American Society of Health-System Pharmacists; 2011. pp. 91-119.

21. Naranjo CA, Busto U, Sellers EM, Sandor P, Ruiz I, Roberts EA, et al. A method for estimating the probability of adverse drug reactions. Clin Pharmacol Ther. 1981;30(2):239-45.
Pan Pan Wang, PharmD, was, at the time of this study, an MSc candidate and Pharmacy Resident at Hôpital du Sacré-Coeur de Montréal (affiliated with Université de Montréal), Montréal, Quebec. She has now completed the MSc program and residency and is a pharmacist at CIUSSS de I'Ouest-de-l'Île-de-Montréal.

Charles-André Bray, PharmD, was, at the time of this study, an MSc candidate and Pharmacy Resident at Hôpital du Sacré-Coeur de Montréal (affiliated with Université de Montréal), Montréal, Quebec. He has now completed the MSc program and residency and is a pharmacist at CIUSSS Centre-Sud-de-l'île-de-Montréal.

Simon Grandjean Lapierre, MD, is a Fellow in Infectious Disease and Medical Microbiology at Hôpital du Sacré-Coeur de Montréal (affiliated with Université de Montréal), Montréal, Quebec.

Hafid Soualhine, PhD, is Supervisor of the Mycobacteriology and Aerobic Actinomycetes Laboratory, Institut national de santé publique du Québec, Sainte-Anne-de-Bellevue, Quebec.

Fanny Arbour, BPharm, MSc, is a Clinical Pharmacist (Pneumology) with the Department of Pharmacy, Hôpital du Sacré-Coeur de Montréal, Montréal, Quebec.

\section{Competing interests: None declared.}

\section{Address correspondence to:}

Fanny Arbour

Department of Pharmacy

Hôpital du Sacré-Coeur de Montréal

5400, boulevard Gouin ouest

Montréal QC H4J 1C5

e-mail: fanny.arbour@umontreal.ca

Funding: None received.

Acknowledgement: This article was written as part of the "Scientific Communication" course for the Faculty of Pharmacy, Université de Montréal. The authors would like to thank the course instructors, especially Mrs Louise Mallet.

\section{ON THE FRONT COVER}

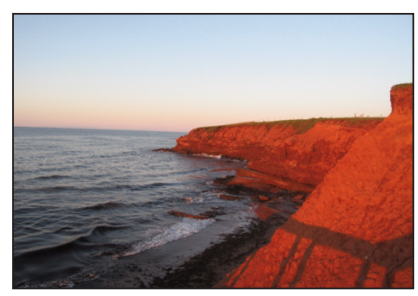

\section{Near Darnley, Prince Edward Island}

CSHP member Natalie Garwah, a Staff Pharmacist with Timmins and District Hospital, describes this issue's cover photograph in her own words: "This photo was taken in June 2010 during a family trip to the East Coast. This site is located near the Twin Shores
Camping Area on Prince Edward Island. After many days of rain, we found this spot during a clear evening drive. It was a spectacular location for an evening photo."

The CJHP would be pleased to consider photographs featuring Canadian scenery taken by CSHP members for use on the front cover of the journal. If you would like to submit a photograph, please send an electronic copy (minimum resolution $300 \mathrm{dpi}$ ) to cjhpedit@cshp.ca. 